\title{
Influence of the addition sequence of PVA-fibers and water on mixing and rheological behavior of mortars
}

\author{
Influência da sequência de adição de fibras e da \\ água no comportamento de mistura e reológico de \\ argamassas com fibras de PVA
}

M. S. DE FRANÇA marylinda.de.franca@Ime.pcc.usp.br

F. A. CARDOSO a fabio.cardoso@Ime.pcc.usp.br

R. G. PILEGGI rafael.pileggi@Ime.pcc.usp.br

\begin{abstract}
The mixing process of fiber-containing cementitious suspensions is a crucial factor to obtaining a good dispersion of fibers and guarantee adequate mechanical performance of the hardened products. The addition of fibers into the suspension causes reduction of the fluidity of the system due to factors inherent to the fibers, the matrix and their interaction. During mixing, these interactions make dispersion and homogenization processes more difficult due to the formation of fibers - particles agglomerates. Conventional techniques to assess workability of mortars are inadequate to evaluate the rheological behavior of fiber-reinforced systems, in which parameters like viscosity and yield stress are not completely taken into account. Therefore, this work employs rotational rheometry to evaluate the influence of fiber and water addition sequences on mixing and rheological behavior of mortars containing Polyvinyl Alcohol (PVA) fibers. Constant test parameters were: mixing time of 317s; impeller velocity $126.5 \mathrm{rpm}$; water flow $128 \mathrm{~g} / \mathrm{s}$. A constant mix design was used with a water content of $16 \% \mathrm{wt}$, and a $0.2 \%$ vol of fibers were added to the reference composition. Four mixing sequences were studied: S1 and S2 are based on the addition of fibers at different stages of the mixing process; while in S3 and S4 not only the fibers are added at different stages, but also the water addition is performed in two steps (25\% first and $75 \%$ latter).Results showed that it is possible to optimize the mixing step of fiber-containing systems by changing the moment of fiber addition into the mixture. The introduction of fibers after mixing the dry mortar with water, when it already had achieved its fluidity point, demanded a lower mixing effort and produced a more flowable material.
\end{abstract}

Keywords: mixing sequence, rheology, PVA fibers.

\section{Resumo}

O processo de mistura de suspensões cimentícias contendo fibras é uma etapa crucial para que se obtenha uma boa distribuição das fibras, garantindo os benefícios que as mesmas podem trazer ao desempenho mecânico. A introdução das fibras na suspensão tende a provocar redução na fluidez. Isso ocorre devido a uma série de fatores inerentes às fibras, à matriz e, à interação entre elas. Durante a mistura, essas interações tornam a dispersão e homogeneização mais difícil devido à formação de aglomerados de partículas e fibras. Técnicas convencionais de avaliação da trabalhabilidade são insuficientes para avaliar o comportamento reológico de sistemas reforçados com fibras porque parâmetros como viscosidade e tensão de escoamento não são considerados em sua totalidade. Assim, este trabalho propõe utilizar técnicas de reometria rotacional, para avaliar a influência da sequência de adição da fibra e da água na mistura e no comportamento reológico de argamassas. O tempo de mistura é mantido fixo em $317 \mathrm{~s}$, a velocidade do equipamento é $126,5 \mathrm{rpm}$ e a taxa de adição de água $128 \mathrm{~g} / \mathrm{s}$ para todas as sequências. Uma mesma composição granulométrica foi usada fixando o teor de água em $16 \%$ e o de fibra em $0,2 \%$. Quatro sequências de mistura foram estudadas: S1 e S2 são baseadas na adição das fibras em diferentes estágios do processo de mistura, enquanto na S3 e S4, não só as fibras são adicionadas em diferentes estágios, mas também a água é adicionada em duas etapas (primeiro $25 \%$ e depois $75 \%$ ). Os resultados indicaram que é possível otimizar o preparo de sistemas com fibras de PVA modificando etapas simples do processo como o momento de introduzir as fibras. Entre as sequências avaliadas concluiu-se que introduzir as fibras após a homogeneização prévia dos materiais, no ponto de fluidez, tende a produzir sistemas mais fluidos e com menor esforço para mistura.

Palavras-chave: sequência de mistura, reologia, fibras de PVA. 


\section{Introduction}

Mixing is the main preparation step of cementitious suspensions, since the adequate dispersion and homogenization of the raw materials in the system is the starting point for fresh and hardened properties to achieve their full potential based on the product's mix design. In this sense, fresh characteristics of the cementitious suspensions like rheological behavior, water retention capacity, and phase separation stability (robustness) are very important because they determine the initial conditions for a suitable microstructural development, which will have substantial effect on the hardened properties of cement-based products.

During mixing, the formation of agglomerates occurs when the liquid (water) get in contact with the solid particles, increasing the necessary efforts for mixing until a point of maximum cohesion between particles is achieved. At this point, the mixing efforts are high and there is a competition between the forces of agglomerate formation and their break. The agglomerates are destroyed by impact and shear energy provided by the mixing equipment, thus, promoting fines and aggregates dispersion, as well as, the homogenization of the solid particles between them and with water [1-6] The efforts related to the mixing process can be assessed by special rheometers capable to withstand and measure the high levels of torque generated during mixing of highly concentrated suspensions (like mortars and concretes) [1-4], or by mixers equipped adequately to quantify the energy consumption [5-7] during the process, also allowing for the identification of the moment that the material starts to behave like a fluid $[2,8]$, the fluidity point. This point can be determined in the mixing curve as the moment in which the torque levels start to stabilize and the first derivative of the curve tends to zero asymptotically, Figure 1 [2].

Mixing stages can be assessed by torque vs. time curves, while shear cycles performed immediately after mixing provide information regarding the effects of mixing on the rheological behavior of the material, Figure 1 [9]. In Figure 1, each red point marked on the curve indicates a mixing time when the rheological profile of a mortar was evaluated by a shear cycle (accelerating and decelerating with steps at different rotation speeds). It can be noted that the shorter the mixing time, the larger the difference between acceleration and deceleration curves (hysteresis), indicating that the system was still rheologically unstable because the mixing was incomplete, therefore the mortar needed an additional energy provided by the shear cycle - to proceed with dispersion and homogenization and, then, achieve a stable state. For longer mixing times, the hysteresis area gets progressively smaller until it zero or almost zero, which indicates that the procedure provided enough energy for an adequate mixing that produced a rheologically stable mortar for the experimental conditions applied [9].

Fibers are generally incorporated into cementitious materials as reinforcements aiming to improve their strength [10], dynamic properties [11,12], resistance to shrinkage cracking and post-failure residual strength [13]. The reinforcement depends on fibers' features - nature, mechanical properties, geometry - their anchorage within the matrix and their dispersion as well. A poor fiber distribution in the matrix promotes little or no reinforcement at all, and it can even generate critical defects within the composite if its concentration is extremely localized [14]. There are various types of fibers used in cementitious matrix: natural, metallic, ceramic, glassy, polymeric and recycled [15]. They are classified in function of the raw material from which they are produced, inorganic or organic types; and they can be also characterized by length, shape and diameter. According to their size, they are called macrofibers (diameter bigger than $0.3 \mathrm{~mm}$ and length from 30 to $60 \mathrm{~mm}$ ) or microfibers (diameter between 10 and $30 \mu \mathrm{m}$ and length between 3 and 18mm) [16].

\section{Figure 1 - Torque vs. time curve and rheological behavior of the reference composition at different mixing times. (adapted (9))}
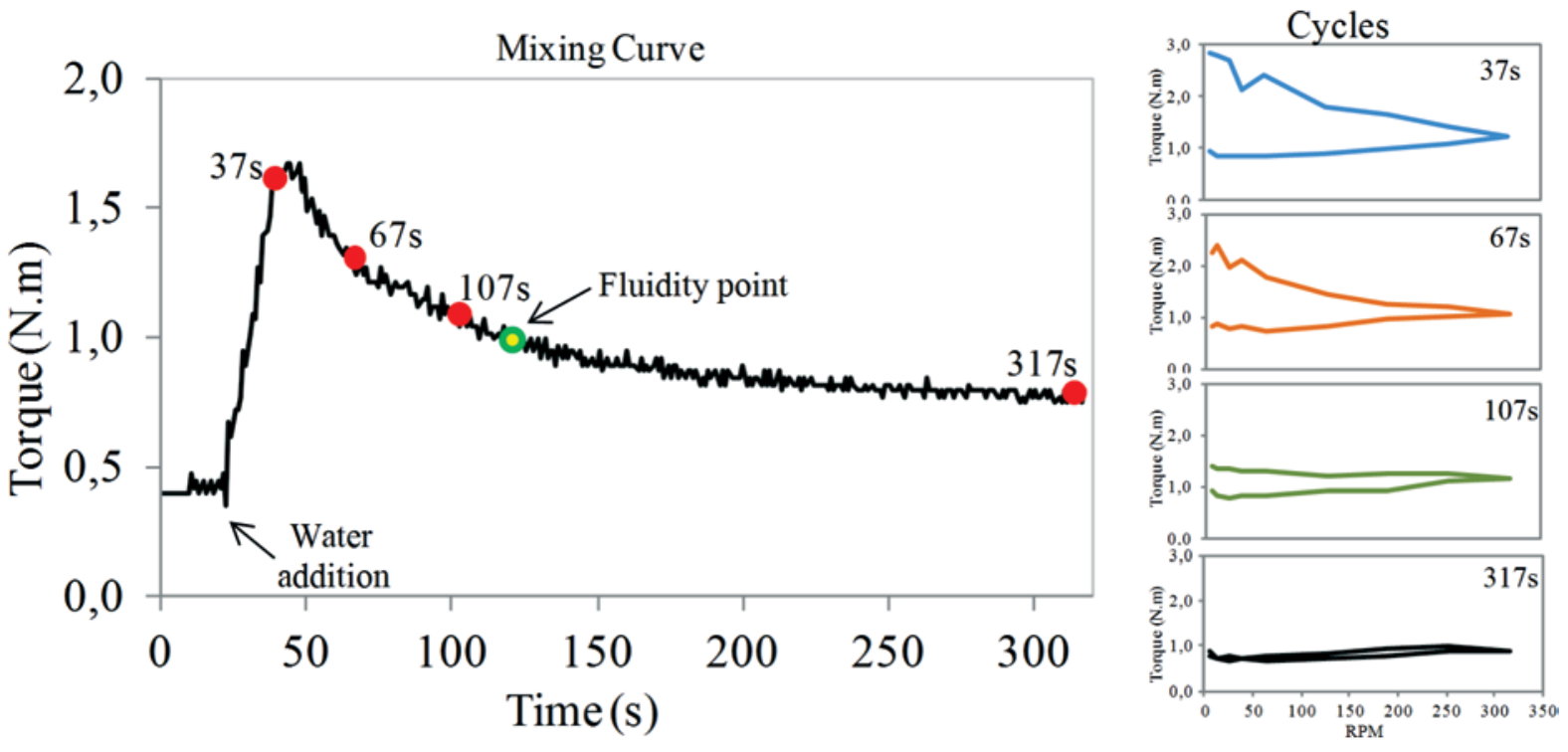
In general, microfibers are used to reduce shrinkage cracking and macrofibers for structural reinforcement [17]. Microfibers present an advantage over the larger ones to prevent cracking because they require a higher pressure to initiate or to propagate cracking due to their smaller diameter [18].

The addition of fibers in cementitious materials causes loss of their workability or reduction of fluidity. This phenomenon is mainly associated to the fiber content, its features (type, geometry, surface treatment, and stiffness), distribution and orientation of the fibers in the matrix, fiber-fiber and fiber-matrix interactions. All these factors make the rheological behavior of fiber-containing suspensions quite complex $[19,20]$.

During mixing, these fiber-related interactions make dispersion and homogenization processes more difficult due to the formation of fibers-particles and even fiber-fiber agglomerates. Trying to reduce / avoid the perturbations caused by fiber interactions during mixing, some authors have suggested different mixing methods and sequences of addition of raw materials to improve the processing of cementitious composites. For mortars reinforced with polypropylene (PP) fibers, it was observed that sequence of addition of the materials and mixing time had influence on the homogeneity of the obtained mortar [21]. Others [22] showed that mixing the fibers with the liquid previously to the particulate materials affected fiber dispersion and consequently the toughness of the composite. An initial mixing of the fibers with the dry particulate materials also reported a better dispersion of sand and fibers [23]. In refractory castables technology, some authors investigating alumina-based concretes with PP fiber addition studied two types of processing: (i) mixing the fibers with the dry materials and (ii) addition of the fibers into the fluid concrete already mixed [4]. The study [4] concluded that depending on the addition method different shear levels during mixing and damage to the fibers were obtained. Damage was lower for shorter fibers and when they were added after the concrete was already mixed [4]. Another investigation also showed better results when the fibers were mixed in the final stage of the processing, after all particulate materials had already been mixed with water [18]. The cementitious composites reinforced with PVA fibers obtained by this mixing method presented a more homogeneous fiber distribution, improved mechanical properties, and reduced shrinkage [18].

The investigations of diverse mixing procedures for fiber-containing cementitious composites seek optimum dispersion of the fibers within the matrix with reduced damaged (that may be caused dur-

\begin{tabular}{|c|c|c|c|}
\hline \multicolumn{4}{|c|}{$\begin{array}{c}\text { Table } 1 \text { - Mix proportions and physical } \\
\text { characteristics (specific gravity, BET specific } \\
\text { surface area) of the raw materials }\end{array}$} \\
\hline $\begin{array}{c}\text { Raw } \\
\text { material }\end{array}$ & $\begin{array}{l}\text { BET } \\
\text { surface area } \\
\left(\mathrm{m}^{2} / \mathrm{g}\right)\end{array}$ & $\begin{array}{l}\text { Stress } \\
(\mathrm{MPa})\end{array}$ & Zone \\
\hline Filler & 1.23 & 2.76 & 12.3 \\
\hline Cement & 1.43 & 3.10 & 14.5 \\
\hline Hydrated Lime CHIII & 6.15 & 2.49 & 4.5 \\
\hline Crushed sand & 0.27 & 2.79 & 68.7 \\
\hline
\end{tabular}

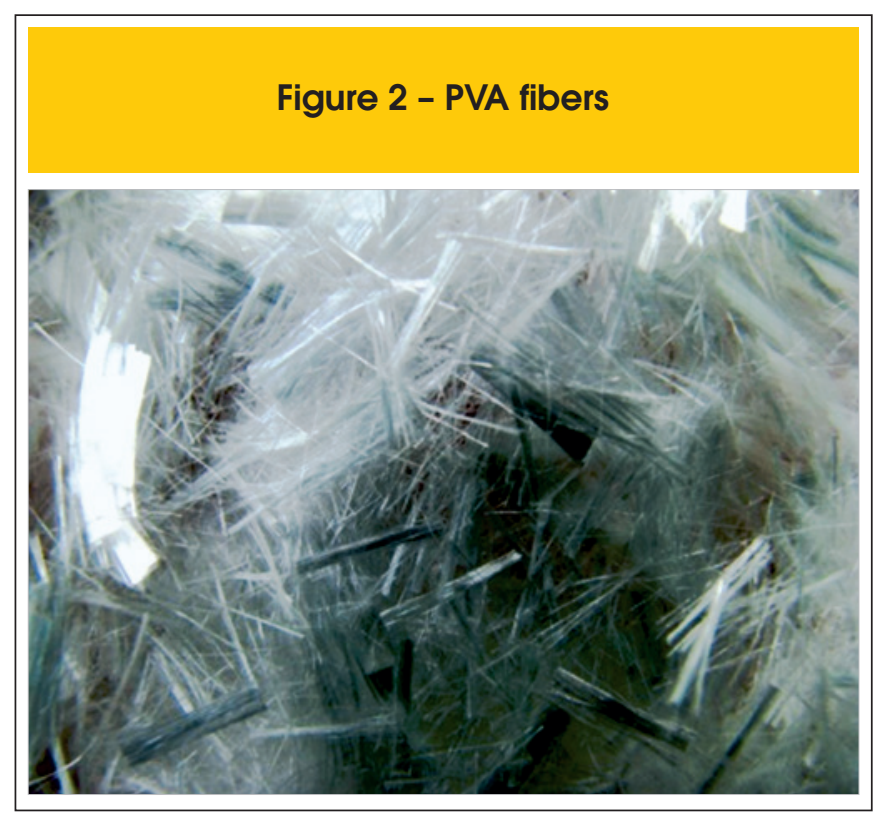

ing processing), in order that the fibers can perform their reinforcement role as expected and, consequently, to produce a composite that can achieve its designed properties. In this context, the goal of the present work is to use rheometry techniques to evaluate the influence of different addition sequences of PVA-fibers and water on mixing and rheological behavior of mortars. Four mixing sequences are studied: S1 and S2 are based on the addition of fibers at different stages of the mixing process; while in S3 and S4 not only the fibers are added at different stages, but also the water addition is performed in two steps ( $25 \%$ first and $75 \%$ latter).

\section{Experimental}

\subsection{Materials}

The reference composition - R - is composed of Portland cement CPII F, hydrated lime Brazilian type $\mathrm{CH}$ III, calcium carbonate filler and crushed sand with maximum particle size of $2 \mathrm{~mm}$. Mix design in volume is demonstrated in Table 1 along with the physical characteristics (specific gravity and specific surface area) of the raw materials. Water content in weight was $16 \%$ for all mixtures (water/ solids ratio of 0.16 ).

Polyvinyl Alcohol or PVA fibers with $6 \mathrm{~mm}$ in length, $16 \mu \mathrm{m}$ of diameter and specific gravity of $1.3 \mathrm{~g} / \mathrm{cm}^{3}$ were employed, Figure 2 . A fiber content of $0.2 \% \mathrm{vol}$ was added to the reference composition ( $0 \%$ of fibers). Before all the mixing procedures with the mortars, the dry fibers were dispersed manually and, then, with the aid of an air jet flow inside a plastic bag.

\subsection{Equipment}

The rotational rheometer for mortars and concretes (Figure 3 ) developed at Poli-USP (Brazil) was used. The equipment performs speed-controlled tests while the electric power of the engine is measured and, then (using calibration constant), converted into torque values. The impeller used in the planetary setup for mixing 
and rheological tests has six blades in spiral configuration, and the blades pass in a minimum distance of $1 \mathrm{~mm}$ from the wall and bottom of the vessel. The device is capable of mixing mortars from dry powder to fluid state and of performing shear cycles for determination of rheological behavior.

\subsection{Mixing sequences}

Four mixing sequences are studied. Sequences S1 and S2 are based on the addition of fibers at different stages of the mixing process: $\mathrm{S} 1$ - fibers are added in the beginning of the process with the particulate materials; S2 - fibers are introduced at the fluidity point. While in S3 and S4 procedures, not only the fibers are added at different stages, but also the water addition is performed in two steps ( $25 \%$ first and $75 \%$ latter). These last sequences were based on previous studies [1,24-26] that showed that the addition of water in two steps increased mixing energy and improved the dispersion of particles. All mixing sequences are described below and in Figure 4.

Mixing sequence $1-\boldsymbol{S 1}$ : Dry PVA fibers previously dispersed are incorporated into the $4 \mathrm{~kg}$-batch of the dry mixture of raw materials and the whole mixture is homogenized inside a plastic bag. Then, this mixture is transferred to the rheometer vessel. The first 20 s of mixing in the rheometer consist of a dry homogenization step, then all the water is added at a rate of $128 \mathrm{~g} / \mathrm{s}$. Mixing continues at 126.5rpm until 317s.

Sequence $2-\boldsymbol{S} 2$ : This sequence is similar to $S 1$, but the mortar is mixed without the fibers, which are added manually for 10 s only at the fluidity point (100s). This point was determined analyzing the mixing curve of sequence $\mathrm{S} 1$ with the same methodology used in [2].

Sequence 3-S3: Dry particulate materials are introduced in the vessel. After 20 s of dry mixing, $25 \%$ of the water are added at a rate of $128 \mathrm{~g} / \mathrm{s}$ and mixed for $120 \mathrm{~s}$. Then, the remaining $75 \%$ of water are added at the same rate and mixing continues. After $120 \mathrm{~s}$, the fibers are introduced manually into the system in 10 s and mixing proceeds until 317s.

Sequence $4-\boldsymbol{S} 4$ : Dry particulate materials are introduced in the vessel. After 20 s of dry mixing, $25 \%$ of the water are added at a rate of $128 \mathrm{~g} / \mathrm{s}$ and mixed for $120 \mathrm{~s}$. Then, the fibers are introduced manually into the system in 10 s and mixing continues. At 200 s, the remaining $75 \%$ of water are added at the same flow rate and mixing proceeds until $317 \mathrm{~s}$.

\subsection{Assessment of mixing behavior}

Batches of $4 \mathrm{~kg}$ of dry material were mixed in the rotational rheometer with the planetary setup (Figure 3). Mixing speed, total mixing time and flow rate of water addition were kept constant and, respectively, equal to: $126.5 \mathrm{rpm}, 317 \mathrm{~s}$, and $128 \mathrm{~g} / \mathrm{s}$. The variation of the torque required to maintain the impeller at a constant rotation speed was monitored by the rheometer during the whole process, from dry material mixing to the end of each procedure (described in 2.3), thus, resulting in the mixing curves as exemplified in Figure 1. The overall work during each mixing sequence is quantified by the area under the torque vs. time curve (integral).

\subsection{Rheological evaluation}

Immediately after mixing, the mortars are subjected to a rotational shear cycle with the same rheometer setup used for mixing (impeller geometry and planetary configuration). The shear cycle consists of accelerating and decelerating the mortar with 5 -second steps at different rotations (6.3; $12.7 ; 25.3 ; 38 ; 63.3 ; 126.5 ; 190,253$; and 316 rpm), as illustrated in Figure 5 . The rheological behavior is obtained from

Figure 3 - a) Rotational rheometer Poli-USP, (1) Rotational device, (2) base reaction and console, (3) elevator, (4) Mortar vessel, (5) mortar impeller; b) Details of impeller

A

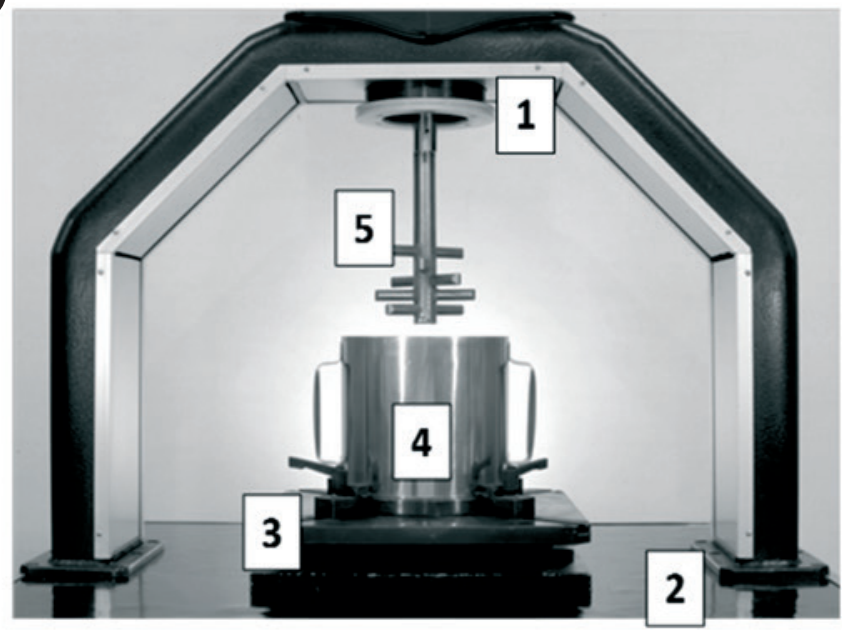

B




Figure 4 - Summary table of mixing sequences
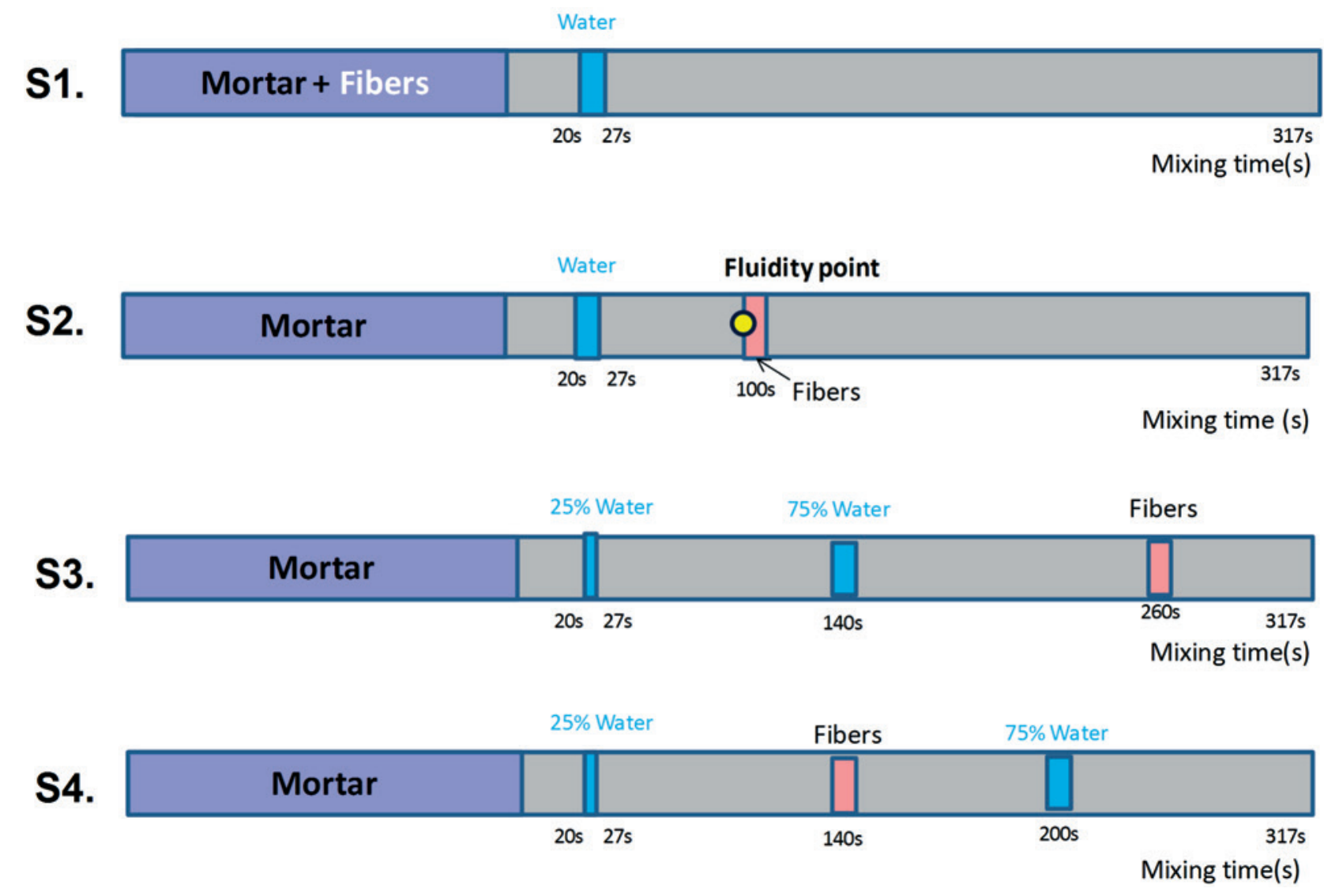

Figure $5-a)$ Rotation program of the shear cycle; b) Typical shear cycle result
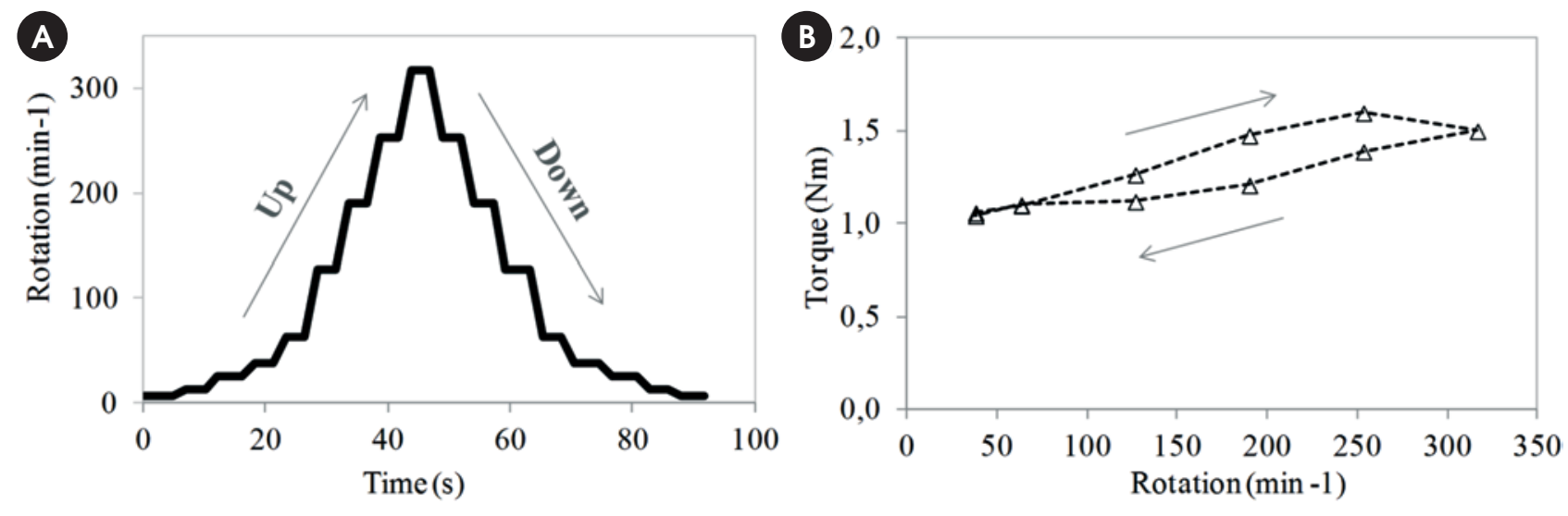


\section{Table 2 - Air content of the mortars prepared by different mixing sequences}

\begin{tabular}{|cccc|}
\hline 0\% fiber & $\begin{array}{c}\text { Air content } \\
(\%)\end{array}$ & 0,2\% fibers & $\begin{array}{c}\text { Air content } \\
(\%)\end{array}$ \\
\hline RS1_0\% & 5.1 & RS1_0.2\% & 5.6 \\
\hline RS2_0\% & 5.1 & RS2_0.2\% & 5.8 \\
\hline RS3_0\% & 4.5 & RS3_0.2\% & 7.8 \\
\hline RS4_0\% & 5.2 & RS4_0.2\% & 6.5 \\
\hline
\end{tabular}

the shear cycle, as well as, the hysteresis area (the difference between acceleration and deceleration curves) that regards the stability condition of the material, therefore, also indicating the mixing efficiency provided by the procedure applied [27].

After the rheological test, fresh density and air content of the mortars were determined by gravimetric method according to the Brazilian standard ABNT NBR 13278 (2005) [28].

\section{Results and discussion}

\subsection{Air content}

Table 2 shows the results of air content entrained in the mortars after the shearing cycle. For the reference composition $(0 \% \mathrm{fi}-$ ber), there is no observed influence of the mixing sequence on the entrained air. The fiber-containing mortars presented a slightly higher air content than the reference compositions, especially for sequences S3 and S4.

\subsection{Mixing curves}

Mixing curves for the mortars prepared by the diverse sequences are demonstrated in Figure 6. For sequences S1 and S2, Figure $6 a$, after water was added torque levels increased rapidly until peak, which corresponds to the point of maximum cohesion of the mixture. Then, shear forces due to intense mixing started to overcome capillary and van de Walls forces breaking the agglomerates and distributing entrapped water throughout the system, causing a gradual decrease of torque. When torque levels tend to stabilize, it marks the point from which the material started to behave as a fluid, i.e. the fluidity point.

The torque levels of the mortars with PVA fibers mixed following S1 are considerably higher than for the reference mortar prepared by the same sequence. Due to the presence of the fibers a strong agglomerate structure is formed, because the non-linear shape of the flexible fibers creates a greater interaction between the particles [20], probably creating bigger agglomerates and mechanical bridging between agglomerates and between the fibers themselves as well. Moreover, van der Waals attractive forces added by the fibers collaborate for the formation of the agglomerates, making dispersion of the fine particles even more difficult and, consequently, increasing mixing efforts and reducing flowability [29].

The fibers were previously mixed with the dry mortar in $\$ 1$ resulting in efforts greater than the ones observed for S2, in which the fibers were added only at the fluidity point. In S1, fibers participate in the formation of the agglomerates since the beginning of the process, having an adverse effect on dispersion and homogenization of particles, also on their own dispersion as well. It reasonably expected that mechanical damaged of the fibers could be more intense in the mortar prepared by $\mathrm{S} 1$ than in the one prepared by $\mathrm{S} 2$ because time and shear, that the fibers were subjected to, are considerably higher in the first than in the latter sequence. In S2, fibers were introduced when the material was already in a fluid condition, at a much lower torque when compared to S1. From this point on, fibers were most homogenized throughout the system and a moderate increase in torque occurred immediately after their addition, but it tended to decrease slightly until the end of the procedure. In the preparation sequences S3 and S4, water was added in two steps (25\% and $75 \%)$; therefore, the mixing curve profile was changed, as illustrated in Figure $6 \mathrm{~b}$. After the initial $25 \%$ of water addition, torque rose abruptly (as for S1 and S2) and reached a plateau $(\approx 5 \mathrm{~N}$.m) until the remaining $75 \%$ of water were introduced at 140 s for S3. The amount of water corresponding to $25 \%$ of the total was not enough for this composition to turn into a fluid-like material, therefore torque levels remained high until the rest of the

\section{Figure 6 - Mixing curves with and without fibers. a) S1 and S2. b) S3 and S4}
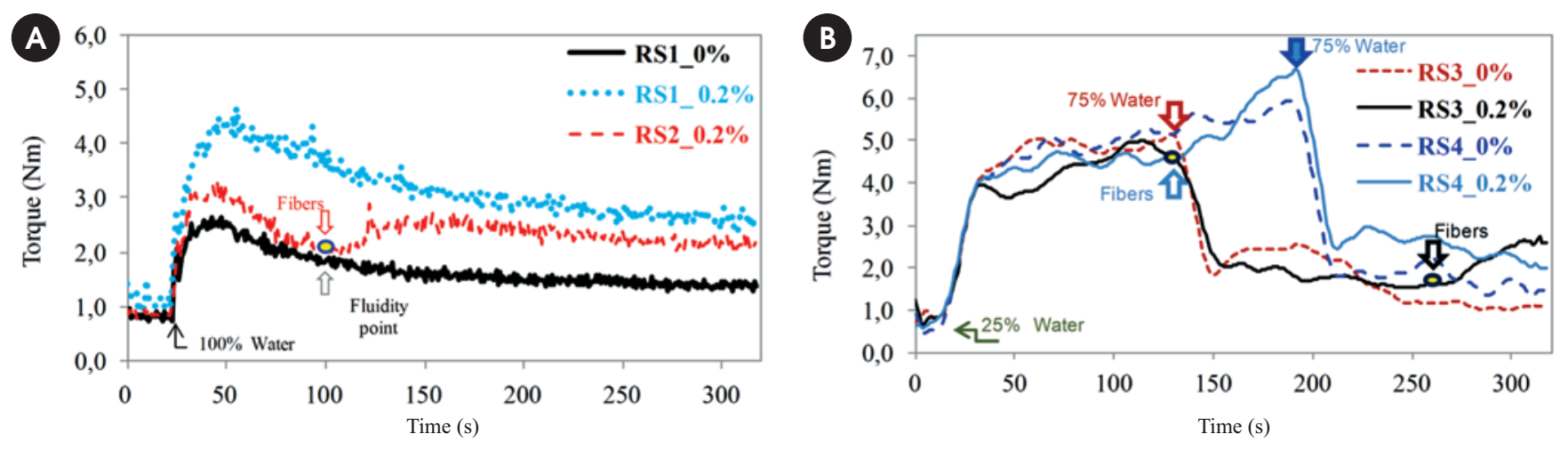


\section{Figure 7 - Scheme of granules formation in the mixture with water and fibers addition according to the $\$ 4$ sequence}

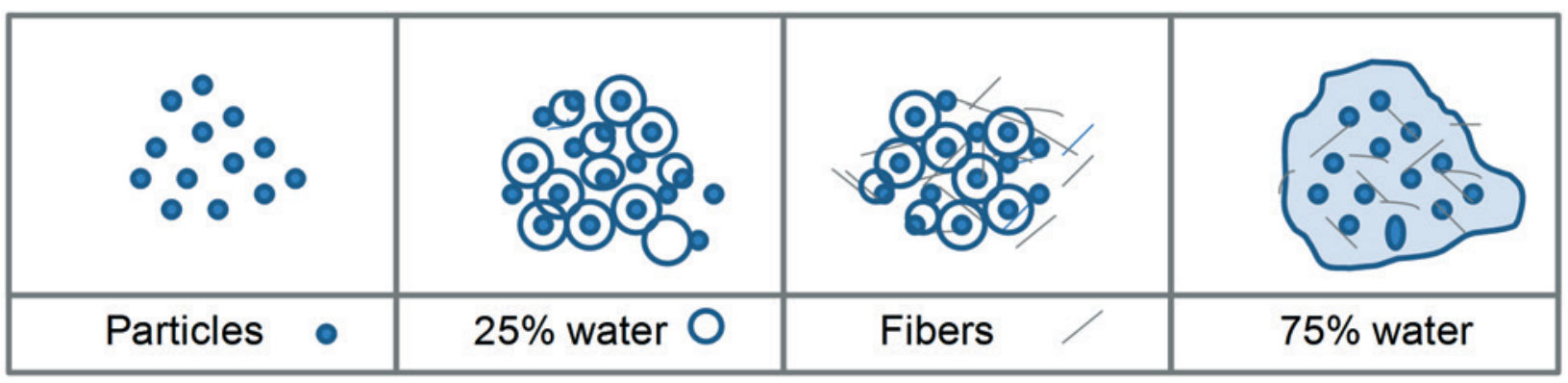

water was added, which caused an instantaneous drop of torque. For the reference mortar, torque levels continued to reduce until the end of the mixing as dispersion and homogenization processes with all the water took place. In S3, fibers were added to the mortar only at 260 s and caused the torque to increase.

The process of adding only $25 \%$ of the water in the beginning of the mixing promoted a pre-homogenization of the raw materials in a low level of liquid saturation. Torque increased until the maximum cohesion state (or capillary forces) was reached when water created capillary bridges surrounding the particles, thus forming small granules (Figure 7). During sequence S4, the fibers were introduced under this high-torque plateau situation, therefore causing the cohesion to increase even more and pushing torque to higher values. As already mentioned, owing to fibers-particles interaction, fibers are likely to create bridges between different granules, thus promoting them to grow and intensifying cohesion forces (both by mechanical bridging and by surface area increase). When the remaining $75 \%$ of water were added, the liquid saturation is reached rapidly and most of the granules are destroyed, increasing interparticle separation distance and the distance between fibers as well, making the system much more disperse and, consequently, more fluid.

The overall work associated to each mixing sequence was quantified by the area under the torque vs. time curves (integral) and results are shown in Table 3. For the reference mortar without fibers, S3 and S4 sequences displayed much larger work values than $\mathrm{S} 1$ because the time mixing with only $25 \%$ of water in S3 and S4 resulted in significantly high torque levels, thus increasing shear energy during the process.

Table 3 - Equivalent work of mixtures according to torque vs. time integral curve

\begin{tabular}{|c|ccc|}
\hline 0\% fiber & $\begin{array}{c}\text { Equivalent } \\
\text { work } \\
\text { (Nm.rad) }\end{array}$ & $\mathbf{0 , 2 \%}$ fibers & $\begin{array}{c}\text { Equivalent } \\
\text { work } \\
\text { (Nm.rad) }\end{array}$ \\
\hline RS1_0\% & 6474 & RS1_0.2\% & 12097 \\
\hline RS2_0\% & 6474 & RS2_0.2\% & 9075 \\
\hline RS3_0\% & 11305 & RS3_0.2\% & 11317 \\
\hline RS4_0\% & 14703 & RS4_0.2\% & 15525 \\
\hline
\end{tabular}

In the case of the mortars with $0.2 \%$ of PVA fibers, adding the fibers at the fluidity point as in S2 reduced the work $25 \%$ compared to S1, in which the fibers were mixed with the particulate materials since the start of the process.

Adding the fibers at the fluidity point, as in $\mathrm{S} 2$, seems to be a more appropriate procedure, because it demands less energy (which also means that it requires an equipment with lower power capacity) and the rheological behavior of the matrix composite, which in this case is the mortar, governs directly fiber dispersion [30]. According to Table 3, S2 resulted in the lowest mixing work compared to the others sequences applied to the compositions with fibers. When comparing S2 and S4, they final torque are similar, but the work associated to the first is considerably lower (42\%) than the work of the last. S3, on the other hand, did not increase the work, but final torque was higher and not yet stabilized since fiber were added at the end of the mixing procedure and did not had time to disperse properly.

Results showed that the sequence of fiber and water addition does have a significant influence on mixing behavior, which may contribute for fiber distribution and reducing the required mixing energy. Work of Zhou et al [31] demonstrated that the plastic viscosity of the mortar before fiber addition needs to be controlled in order to promote a good fiber distribution and that changes in the mixing sequence can improve the process.

\subsection{Rheological behavior}

Figure 8a shows the results of the shear cycles for sequences $\mathrm{S} 1$ and S2. The mortar without fibers (RS1_0\%) display a curve with much lower toque levels than the fiber-containing mortar mixed following sequence S1 (RS1_0.2\%). Hysteresis area for RS1_0\% is also lower than for RS1_0.2\%. For S2, in which the fiber were added at the fluidity point, torque levels are an intermediate position between the reference composition and RS1_0.2\%, which are in accordance to final mixing torques showed in Figure $6 a$.

For sequences S3 and S4 0\% fibers, Figure 8b, torque levels of the shear cycle are lower than the mortars with fibers but slightly higher than RS1_0\%, especially at high rotation speeds. The mortars with fibers prepared by S3 and S4 displayed torque levels two times greater than the reference mortars prepared by the same procedures; also, they presented the largest hysteresis areas of all curves. 


\section{Figure 8 - Results of shear cycles of mortars. a) S1 and S2. b) S3 and S4}

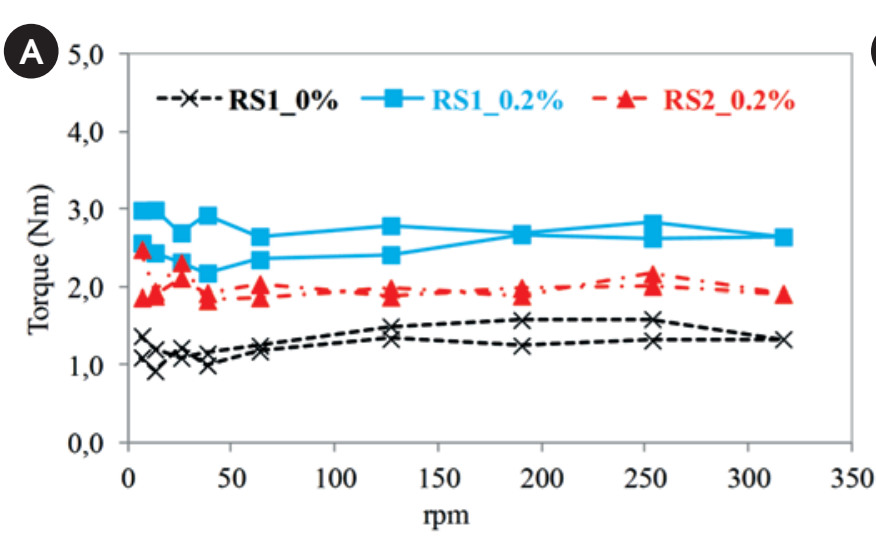

From the shear cycles of Figure 8, it can be seen that the mortars without fibers presented lower yield torque than the fiber-containing ones. Amongst the mortars with fibers, S2_0.2\% had the lowest yield torque of them, which indicates a lower demand of initial stress to begin flowing, while S3_0.2\% displayed the highest yield torque of them all.

Ultimately, for the experimental conditions employed it this study, the sequence $\mathrm{S} 2$ showed the best performance regarding the mixing process of fiber-containing mortars, as well as, it promoted the mortar with the most flowable rheological behavior. Adding the fibers at the fluidity point not only reduced the overall energy required to mixing the system, but it also decreased yield torque and torque levels of the shear cycle.

\section{Conclusions}

In this work, four different addition sequences of water and PVA fibers were evaluated. The mixing process had a great influence on the rheological behavior of fiber-containing mortars, especially regarding the moment of fiber addition during the procedure. When the fibers were added in the beginning of the procedure - still in the dry composition - they demanded much higher mixing efforts than when they were added after an initial mixing of the particulate materials with water. The two-step water addition procedures did not improve the rheological behavior of the mortars with fibers and it even increased the overall mixing work of these systems.

The introduction of the fibers at the fluidity point - sequence S2 - reduced significantly the mixing work and improved the rheological behavior of the mortar when compared to the other mixing sequences. Therefore, this study showed that it is possible to optimize the mixing behavior of mortars containing PVA fibers by simple modifications in the addition sequence of water and fibers.

\section{References}

[1] Pileggi RG, Studart AR, Pandolfelli VC, Gallo J. How mixing affects the rheology of refractory castables, Part 1. Am Ceram Soc Bull 2001;80:27-31.

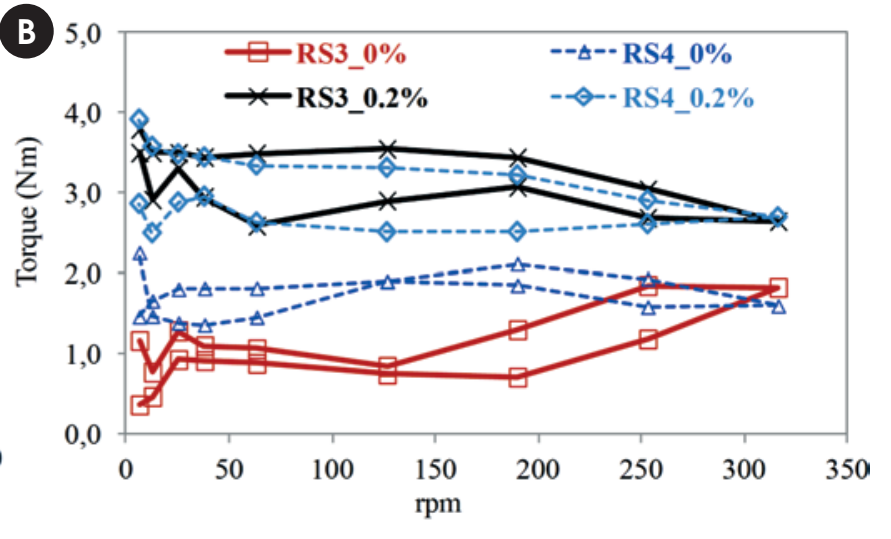

[2] França MS de. COMPORTAMENTO DE MISTURA DE SISTEMAS CIMENTÍCIOS MULTIFÁSICOS REATIVOS -Mixing behavior of multiphase cementitious materials. Master's Dissertation. Escola Politécnica da Universidade de São Paulo, 2012.

[3] Cavinato M, Bresciani M, Machin M, Bellazzi G, Canu P, Santomaso A. The development of a novel formulation map for the optimization of high shear wet granulation. Chem Eng J 2010;164:350-8. doi:10.1016/j.cej.2010.05.006.

[4] Domiciano VG, Salomão R, Isaac CS, Pandolfelli VC. Processing conditions and the permeability of polymeric fibercontaining refractory castables. Cerâmica 2003;49:251-6. doi:10.1590/S0366-69132003000400010.

[5] Leuenberger H, Puchkov M, Krausbauer E, Betz G. Manufacturing pharmaceutical granules: Is the granulation end-point a myth? Powder Technol 2009;189:141-8. doi:10.1016/j. powtec.2008.04.005.

[6] Cazacliu B, Roquet N. Concrete mixing kinetics by means of power measurement. Cem Concr Res 2009;39:182-94. doi:10.1016/j.cemconres.2008.12.005.

[7] Rondet E, Denavaut M, Mandato S, Duri A, Ruiz T, Cuq B. Power consumption profile analysis during wet agglomeration process: Energy approach of wheat powder agglomeration. Powder Technol 2012;229:214-21. doi:10.1016/j.powtec.2012.06.035.

[8] Cazacliu B, Legrand J. Characterization of the granular-tofluid state process during mixing by power evolution in a planetary concrete mixer. Chem Eng Sci 2008;63:4617-30. doi:10.1016/j.ces.2008.06.001.

[9] França MS de, Cardoso FA, Pileggi RG. Mixing behavior of mortars evaluated by rotational rheometry. Ambiente Construído 2012;12:165-74. doi:10.1590/S167886212012000200011

[10] BENTUR A, MINDESS S. Fibre Reinforced Cementitious Composites. 2nd ed. Londond and New York: 2007.

[11] Noushini A, Samali B, Vessalas K. Effect of polyvinyl alcohol (PVA) fibre on dynamic and material properties of fibre reinforced concrete. Constr Build Mater 2013;49:374-83. doi:10.1016/j.conbuildmat.2013.08.035. 
[12] Liu J, Sun W, Miao C, Liu J, Li C. Assessment of fiber distribution in steel fiber mortar using image analysis. J Wuhan Univ Technol-Mater Sci Ed 2012;27:166-71. doi:10.1007/ s11595-012-0429-z.

[13] Bolander JE, Choi S, Duddukuri SR. Fracture of fiber-reinforced cement composites: Effects of fiber dispersion. Int $\mathrm{J}$ Fract 2008;154:73-86. doi:10.1007/s10704-008-9269-4.

[14] Ozyurt N, Mason TO, Shah SP. Correlation of fiber dispersion, rheology and mechanical performance of FRCs. Cem Concr Compos 2007;29:70-9. doi:10.1016/j.cemconcomp.2006.08.006.

[15] Campello E, Pereira MV, Darwish F. The Effect of Short Metallic and Polymeric Fiber on the Fracture Behavior of Cement Mortar. Procedia Mater Sci 2014;3:1914-21. doi:10.1016/j.mspro.2014.06.309.

[16] SALVADOR RP. Análise comparativa de métodos de ensaio para caracterização do comportamento mecânico de concreto reforçado com fibras. Dissertação (Mestrado em Engenharia de Construção Civil e Urbana). Escola Politécnica, University of São Paulo, 2012.

[17] Ding Y, Liu S, Zhang Y, Thomas A. The investigation on the workability of fibre cocktail reinforced self-compacting high performance concrete. Constr Build Mater 2008;22:146270. doi:10.1016/j.conbuildmat.2007.03.034.

[18] Kim B, Boyd AJ, Lee J-Y. Effect of transport properties of fiber types on steel reinforcement corrosion. J Compos Mater 2011;45:949-59. doi:10.1177/0021998310380286.

[19] GRÜNEWALD S. Performance - based design of self-compacting fibre reinforced concrete. These. Delft University of Technology., 2004.

[20] Keshtkar M, Heuzey MC, Carreau PJ. Rheological behavior of fiber-filled model suspensions: Effect of fiber flexibility. J Rheol 2009;53:631. doi:10.1122/1.3103546.

[21] SILVA R da P. Argamassas com adição de fibras de polipropileno - Estudo do comportamento reológico e mecânico. Dissertação (Mestrado em Engenharia de Construção Civil e Urbana). Escola Politécnica da Universidade de São Paulo, 2006.

[22] Akkaya Y, Shah S, Ankenman B. Effect of Fiber Dispersion on Multiple Cracking of Cement Composites. J Eng Mech 2001;127:311-6. doi:10.1061/(ASCE)07339399(2001)127:4(311).

[23] Kuder KG, Ozyurt N, Mu EB, Shah SP. Rheology of fiber-reinforced cementitious materials. Cem Concr Res 2007;37:191-9. doi:10.1016/j.cemconres.2006.10.015.

[24] Zhou J, Qian S, Ye G, Copuroglu O, van Breugel K, Li VC. Improved fiber distribution and mechanical properties of engineered cementitious composites by adjusting the mixing sequence. Cem Concr Compos 2012;34:342-8. doi:10.1016/j. cemconcomp.2011.11.019.

[25] ANTUNES R. Influência da Reologia e da Energia de Impacto na Resistência de Aderência de Revestimentos de Argamassa. Escola Politécnica da Universidade de São Paulo, 2005.

[26] Cardoso FA. Método de Formulação de Argamassas de Revestimento Baseado em Distribuição Granulométrica e Comportamento Reológico. Escola Politécnica da Universidade de São Paulo, 2009.
[27] França MS de, Cardoso FA, Pileggi RG. Influence of laboratory mixing procedure on the properties of mortars. Ambiente Construído 2013;13:111-24. doi:10.1590/S167886212013000200009.

[28] Pileggi RG, Studart AR, Pandolfelli VC, Gallo J. How mixing affects the rheology of refractory castables, Part 2. Am Ceram Soc Bull 2001;80:38-42.

[29] ABNT NBR 13278. ASSOCIAÇÃO BRASILEIRA DE NORMAS TÉCNICAS. NBR 13278: argamassa para assentamento e revestimento de paredes e tetos - Determinação da densidade de massa e do teor de ar incorporado 2005.

[30] Collins F, Lambert J, Duan WH. The influences of admixtures on the dispersion, workability, and strength of carbon nanotube-OPC paste mixtures. Cem Concr Compos 2012;34:201-7. doi:10.1016/j.cemconcomp.2011.09.013.

[31] Li M, Li VC. Rheology, fiber dispersion, and robust properties of Engineered Cementitious Composites. Mater Struct 2013;46:405-20. doi:10.1617/s11527-012-9909-z. 